\title{
Profil Hipertensi pada Anak di RSUD Dr. Zainoel Abidin Banda Aceh
}

\author{
Syafruddin Haris, Herlina Dimiati, M.Sidqi Anwar
}

Departemen Ilmu Kesehatan Anak Fakultas Kedokteran Universitas Syiah Kuala-Rumah Sakit Zainoel Abidin, Banda Aceh

\begin{abstract}
Latar belakang. Hipertensi pada anak masih mendapat perhatian yang serius karena dapat menimbulkan cacat menetap dan berakibat kematian. Prevalensi hipertensi anak tidak diketahui secara pasti, dilaporkan sekitar 1\%-5\%. Hipertensi tersering yang dijumpai di rumah sakit rujukan adalah hipertensi sekunder. Tujuan. Mengetahui profil klinis dan respon terapi pasien hipertensi pada anak di ruang rawat inap anak RSUD Zainoel Abidin (RSUDZA), Banda Aceh selama periode 5 tahun.

Metode. Penelitian deskriptif retrospektif untuk melihat gambaran hipertensi pada anak di RSUDZA. Data diperoleh dari catatan medik pasien hipertensi sejak tahun 2007 - 2011. Data dikumpulkan berdasarkan derajat hipertensi, penyakit yang mendasari hipertensi, dan pengobatan yang diberikan.

Hasil. Selama 5 tahun (2007-2011), terdapat 41 pasien hipertensi (26 laki-laki dan 15 perempuan). Hipertensi derajat satu 10 orang, derajat dua 16 orang, dan hipertensi krisis 15 orang. Umur tersering adalah 10-11 tahun. Tidak terdapat hubungan antara rerata umur dengan derajat hipertensi. Penyakit yang mendasari adalah 16 orang glomerolunefritis akut, 13 sindrom nefrotik, 7 gagal ginjal kronik, serta 5 penyakit lainnya. Tidak terdapat hubungan yang bermakna antara penyakit yang mendasari dengan derajat hipertensi. Respon pengobatan hipertensi dengan satu macam obat 9 orang, dua obat 19, dan 13 respon dengan gabungan tiga atau lebih obat. Terdapat hubungan yang bermakna antara jumlah obat dengan derajat hipertensi.

Kesimpulan. Hipertensi pada anak di RSUDZA paling sering terdapat anak berumur 10-11 tahun. Penyebab tersering adalah glomerulonefritis akut. Terdapat hubungan bermakna antara jumlah obat yang diberikan dengan derajat hipertensi. Sari Pediatri 2013;15(2):105-110.
\end{abstract}

Kata kunci: hipertensi primer, hipertensi sekunder, derajat hipertensi,glomerulonefritis akut

\footnotetext{
Alamat korespondensi:

Dr. Syafruddin Haris, Sp.A. Bagian Ilmu Kesehatan Anak FK-Unsyiah/ RSUD Dr. Zainoel Abidin. Jl. Tgk. Daud Beureueh No. 108 Banda Aceh, Telp/Fax.: (0651) 7122798. E-mail : harissyafruddin@idai.or.id
}

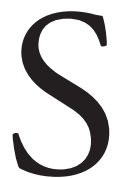
ebagian orang beranggapan bahwa hipertensi hanya terjadi pada orang dewasa atau jarang terjadi pada anak. Namun, setelah publikasi task force on blood pressure in children-1977 dan 1987 terbukti bahwa hipertensi pada anak merupakan masalah klinik penting karena dapat langsung berwujud sebagai penyakit yang berakibat kematian, 
atau secara tidak langsung menimbulkan cacat menetap setelah proses akutnya sembuh. ${ }^{1}$ Hipertensi pada anak dibagi dua kategori, yaitu hipertensi primer apabila penyebab hipertensi tidak dapat dijelaskan atau tidak diketahui penyakit dasarnya, biasanya berhubungan dengan faktor keturunan, masukan garam, stress, dan kegemukan; ${ }^{2,3}$ serta hipertensi sekunder terjadi akibat penyakit lain yang mendasarinya. ${ }^{4}$ Penelitian selama ini menunjukkan hipertensi pada anak terbanyak bersifat sekunder. ${ }^{5}$ Penyebab hipertensi pada anak hampir $80 \%$ berasal dari penyakit ginjal. Biasanya timbul dalam bentuk akut atau berlangsung kronik. ${ }^{4,5}$

Prevalensi hipertensi anak tidak diketahui secara pasti bergantung pada definisi yang dipergunakan, tetapi menurut kepustakaan prevalensinya 1\%-5\% populasi anak. Hipertensi berat terdapat pada $10 \%$ dari hipertensi keseluruhan atau $0,1 \%$ populasi anak, dan biasanya hipertensi sekunder yang memerlukan pengobatan dan lebih sering dijumpai di rumah sakit rujukan. ${ }^{6}$ Diperkirakan 2/3 anak dengan hipertensi akan menderita kerusakan ginjal di kemudian hari apabila tidak ditangani dengan tepat. Banyak faktor yang memengaruhi tekanan darah anak. Anak yang lebih berat atau lebih tinggi badannya mempunyai nilai tekanan darah yang lebih tinggi dibandingkan anak sebaya yang lebih kurus dan pendek. ${ }^{7}$ Hipertensi primer kebanyakan dijumpai pada remaja laki-laki dalam bentuk derajat ringan dan biasanya tidak menunjukkan gejala klinis. Gejala umum yang timbul pada anak adalah sakit kepala, pusing, penglihatan kabur, nyeri perut, muntah, nafsu makan berkurang, gelisah,berat badan turun, dan keringat berlebihan.7,8

Rumah Sakit Zainoel Abidin, Banda Aceh, adalah rumah sakit rujukan di Propinsi Aceh. Sampai saat ini belum ada laporan kejadian hipertensi khususnya hipertensi pada anak di rumah sakit tersebut. Data tentang anak hipertensi sangatlah penting karena menentukan langkah selanjutnya dalam mengatasi hipertensi. Berdasarkan hal tersebut, penulis melakukan penelitian untuk mengetahui profil klinis dan respon terapi pasien hipertensi pada anak di RSUDZA, Banda Aceh selama 5 tahun.

\section{Metode}

Penelitian deskriptif retrospektif dengan data diambil dari catatan medik pasien hipertensi yang berobat di Bagian Ilmu Kesehatan Anak FK-UNSYIAH RSUDZA, Banda
Aceh, sejak tahun 2007 - 2011. Catatan medik hingga tahun 2006 tidak lengkap karena hilang atau rusak oleh peristiwa tsunami dan pembenahan rumah sakit. Data yang dikumpulkan meliputi umur, jenis kelamin, derajat hipertensi, penyakit yang mendasari hipertensi, dan pengobatan hipertensi yang diberikan selama rawatan. Hipertensi pada anak didefinisikan berdasarkan National High Blood Pressure Education Program Working Group on High Blood Pressure in Children and Adolescents (2004) yang telah direvisi. Hipertensi diartikan apabila tekanan darah sistolik atau diastolik $\geq$ persentil $95^{\text {th }}$ berdasarkan umur, jenis kelamin, dan tinggi badan pada $\geq 3$ kali pemeriksaan saat yang berbeda. Hipertensi dibagi menjadi dua stadium. Hipertensi stadium 1 adalah hipertensi dengan tekanan darah berkisar antara persentil $\geq 95^{\text {th }}$ sampai persentil $99^{\text {th }}$ plus $5 \mathrm{mmHg}$ berdasarkan umur, jenis kelamin, dan tinggi badan. Hipertensi stadium 2 adalah hipertensi dengan tekanan darah $\geq$ persentil $99^{\text {th }}$ plus $5 \mathrm{mmHg}$ berdasarkan umur, jenis kelamin, dan tinggi badan. ${ }^{10}$ Hipertensi krisis didefinisikan sebagai tekanan darah sistolik $>180$ $\mathrm{mmHg}$ dan atau diastolik $>120 \mathrm{mmHg}$ atau setiap tingkat hipertensi yang disertai komplikasi ensefalopati hipertensi, gagal jantung, dan edema papil. Pada bayi dan anak berumur $<5$ tahun, digunakan definisi hipertensi krisis jika tekanan darahmeningkat $50 \%$ dari nilai tekanan darah normal atau $>1 \frac{1 / 2}{2}$ kali batas atas tekanan darah normal berdasarkan umur dan jenis kelamin. ${ }^{6}$

Pengobatan hipertensi secara farmakologi terdiri atas diuretik atau penghambat enzim konverting angiotensin mulai dengan dosis minimal dan bila diperlukan dosis dapat dinaikkan sampai mencapai dosis maksimal. Jika tekanan darah tidak turun, dilanjutkan dengan menambahkan angiotensin receptor blocker atau mengganti dengan penghambat adrenergik. Jika tekanan darah tidak turun juga, baru ditambahkan nifedipin atau amblodipin. Pada pasien hipertensi krisis, tekanan darah diturunkan dalam waktu 1 jam dengan pemberian nifedipin sublingual atau oral. ${ }^{11}$ Data ditampilkan berdasarkan distribusi frekuensi (\%)

\section{Hasil}

Selama 5 tahun (2007-2011), didapatkan 4670 anak yang dirawat di Bagian Ilmu Kesehatan Anak RSUDZA, 175(3,7\%) pasien dirawat di Divisi Nefrologi, dan 41(23,4\%) pasien di antaranya adalah hipertensi atau 8 kasus per tahun. Keempat puluh satu 
pasien ini terdiri atas 26 laki-laki dan 15 perempuan yang berumur antara $4-16$ tahun, dan umur yang tersering adalah 10-11 tahun (Tabel 1).

Derajat hipertensi yang didapat adalah hipertensi tingkat satu 10 orang, hipertensi tingkat dua 16, dan hipertensi krisis 15 orang. Tabel 2 menunjukkan hubungan umur dengan derajat hipertensi. Tidak terdapat perbedaan bermakna rerata umur dengan derajat hipertensi.

Penyebab hipertensi adalah glomerulonefritis akut (GNA) 16/41, sindrom nefrotik 13/41, gagal ginjal kronik (GGK) 7/41, dan 5/41 penyakit lain

Tabel 1.Distribusi hipertensi menurut umur dan jenis kelamin

\begin{tabular}{lccc}
\hline Umur (tahun) & Laki-laki & Perempuan & Jumlah \\
\hline$<4$ & 1 & 0 & 1 \\
$4-5$ & 2 & 1 & 3 \\
$6-7$ & 2 & 2 & 4 \\
$8-9$ & 3 & 1 & 4 \\
$10-11$ & 10 & 3 & 13 \\
$12-13$ & 3 & 4 & 7 \\
$>13$ & 5 & 4 & 9 \\
\hline Jumlah & 26 & 15 & 41 \\
\hline
\end{tabular}

Tabel 2. Hubungan umur dengan derajat hipertensi

\begin{tabular}{lccc}
\hline & $\mathrm{n}$ & Rerata umur \pm SD & $\mathrm{p}$ \\
\hline Hipertensi grade I & 10 & $10,4 \pm 3,86$ & $0,362^{*}$ \\
Hipertensi grade II & 16 & $9,5 \pm 3,53$ & \\
Hipertensi krisis & 15 & $11,4 \pm 3,31$ & \\
\hline
\end{tabular}

*uji Anova (obesitas, thalassemia, epilepsi, neurofibroma). Tabel 3 menunjukkan bahwa GNA merupakan penyebab hipertensi tersering.

Untuk kepentingan analisis data, hipertensi grade I dan II dikelompokkan menjadi satu kelompok, sedangkan hipertensi krisis menjadi satu kelompok. Penggabungan data ini masih logis karena hipertensi krisis merupakan jenis hipertensi yang mengancam jiwa jika dibandingkan hipertensi grade I dan II. Demikian pula untuk GNA dan sindrom nefrotik merupakan masing-masing kelompok, dan GGK serta penyakit lain dimasukkan ke dalam kelompok penyakit ginjal kronik. Penggolongan diagnosis GGK dan penyakit lain menjadi satu kelompok karena merupakan bagian dari penyakit ginjal kronis.

Tabel 4 menunjukkan bahwa hubungan diagnosis dengan derajat hipertensi tidak bermakna. Hipertensi krisis lebih sering dijumpai pada penyakit ginjal kronis, sedangkan hipertensi grade I dan II lebih sering dijumpai pada GNA dan sindrom nrfotik, tetapi hubungan tersebut tidak bermakna.

Respon terhadap obat antihipertensi berbeda-beda. Respon pengobatan hipertensi dengan obat tunggal (furosemid) terdapat 9 orang, respon pengobatan dengan dua obat (furosemiddannifedipin) 19 orang, dan selebihnya 13 orang memberikan respon dengan gabungan lebih tiga obat (furosemid, kaptopril, amlodipin). Tabel 4 menunjukkan hubungan antara respon obat dengan derajat hipertensi. Hubungan antara jumlah obat dan derajat hipertensi bermakna, yaitu hipertensi krisis memerlukan lebih dari satu macam obat dibandingkan hipertensi derajat I dan II.

Tabel 3. Hubungan diagnosis dengan derajat hipertensi

\begin{tabular}{lcccc}
\hline & Hipertensi grade I & Hipertensi grade II & Hipertensi krisis & Jumlah \\
\hline GNA & 2 & 8 & 6 & 16 \\
Sindrom nefrotik & 8 & 4 & 1 & 13 \\
GGK & 0 & 2 & 5 & 7 \\
Penyakit lain & 0 & 2 & 3 & 5 \\
\hline
\end{tabular}

Tabel 4. Hubungan diagnosis dengan derajat hipertensi

\begin{tabular}{lccc}
\hline & Hipertensi grade I \& II & Hipertensi krisis & p \\
\hline GNA & 10 & 6 & $0,129^{*}$ \\
Sindrom nefrotik & 12 & 1 & \\
Penyakit ginjal kronis & 4 & 8 & \\
\hline
\end{tabular}

*uji Kolmogorov Smirnov 
Tabel 5. Terapi hipertensi berdasarkan derajat hipertensi

\begin{tabular}{lccc}
\hline Obat & HT grade I\&II & Krisis HT & p \\
\hline Satu & 9 & 0 & 0,002 \\
Dua & 16 & 3 & \\
Tiga atau lebih & 1 & 12 & \\
\hline
\end{tabular}

*uji Kolmogorov Smirnov

\section{Pembahasan}

Insiden hipertensi di RSUDZA Banda Aceh adalah 23,4\%, dan hasil tersebut tidak jauh berbeda dengan penelitian Pungky dan Damanik ${ }^{12}$ di RS Dr.Sardjito Yogyakarta, yaitu 26,9\%. Pada penelitian kami, penyebab terbanyak hipertensi adalah GNA.. Penelitian lain juga melaporkan bahwa GNA sebagai penyebab hipertensi. ${ }^{13}$ Penyakit parenkim ginjal merupakan penyebab utama hipertensi pada anak preadolesen. ${ }^{10,14}$ Glomerulonefritis, anomali kongenital, nefropati refluks, dan pielonefritis merupakan penyebab hipertensi yang paling umum terjadi pada rentang umur 0-18 tahun. ${ }^{15}$ Tujuh puluh hingga $85 \%$ hipertensi pada anak merupakan hipertensi sekunder sehingga diagnosis banding penyebab hipertensi berdasarkan umur perlu diperhatikan. ${ }^{15-17}$

Pada penelitian kami, umur tersering menderita hipertensi adalah 10-11 tahun, sedangkan dibawah umur tersebut tidak banyak dijumpai. Tidak terdapat hubungan antara rerata umur dengan derajat hipertensi. Hal tersebut berbeda dengan penelitian di Cina, ditemukan bahwa umur muda lebih sering mengalami hipertensi krisis. ${ }^{18}$ Perbedaan tersebut disebabkan umur yang sering dijumpai pada penelitian adalah 10-11 tahun sehingga pada umur yang amat muda (dibawah umur 5 tahun) tidak dapat dijelaskan hubungannya dengan derajat hipertensi.

Pada penelitian didapatkan kecenderungan hipertensi berat, seperti hipertensi tingkat grade II sebesar (16/41) dan hipertensi krisis (15/41). Penelitian lain di RS Sardjito Yogyakarta, ditemukan hipertensi berat sebesar $70 \% .{ }^{12}$ Penelitian tersebut membedakan hipertensi berdasarkan berat, sedang, dan ringan. Pada penelitian kami derajat dengan prehipertensi tidak dapat ditampilkan karena data direkam medik tidak tercantum. Hal tersebut disebabkan pemeriksaan tekanan darah tidak rutin dilakukan pada setiap pasien sehingga hipertensi tidak terdeteksi, atau walaupun tekanan darah diukur, tetapi tidak diinterpretasi dengan tabel Task Force $2004^{11}$ sehingga tidak terdiagnosis. Hal tersebut menunjukkan bahwa dokter di unit gawat darurat sering under estimate/under diagnosed terhadap anak dengan hipertensi.

Umumnya hipertensi sekunder pada anak dapat didiagnosis melalui anamnesis, pemeriksaan fisik, pemeriksaan tekanan darah pada keempat ekstremitas, dan pemeriksaan penunjang (urinalisis, darah, ureum, kreatinin, dan pencitraan). Penegakan diagnosis menjadi lebih sulit pada anak dengan hipertensi sekunder jika tanda klinis yang nyata tidak terlihat. Hal tersebut terjadi pada anak dengan hipertensi onset cepat atau resistensi hipertensi. Pendekatan berdasarkan umur dalam mendiagnosis penyebab hipertensi pada keadaan seperti ini menjadi penting. ${ }^{15,17} \mathrm{Hal}$ yang sama juga terjadi di RSUDZA, 12,2\% pasien dengan penyakit lain tidak diketahui penyebab hipertensinya karena keterbatasan tenaga dan pemeriksaan, padahal hipertensi kronis paling sering berhubungan dengan penyakit parenkim ginjal (70\%-80\%), hipertensi renovaskular (10\%$15 \%)$, koartasio aorta (5\%-10\%), feokromasitoma, dan penyebab endokrin lainnya (1\%-5\%). ${ }^{19}$

Pada evaluasi kasus baru hipertensi pada anak perlu difikirkan kerusakan target organ dan prognosis pasien. Kebanyakan hipertensi sekunder pada anak merupakan hipertensi berat, bahkan terjadi hipertensi krisis atau hipertensi ensefalopati seperti terdapat pada penelitian kami. Tata laksana pasien biasanya dilakukan di unit gawat darurat dan ruang intensif untuk memantau fungsi jantung, status neurologis, dan volume urin. Tujuan pemberian anti hipertensi adalah menurunkan tekanan arteri rata-rata (mean arterial pressure) 25\% dalam 8 hingga 12 jam, selanjutnya penurunan tekanan darah sepertiganya lagi pada $12-36$ jam berikut. ${ }^{20,21}$ Apabila tekanan darah telah terkontrol dan fase akut telah selesai, lakukan pemeriksaan ekstensif untuk mencari etiologi hipertensi tersebut. ${ }^{21}$

Pada penelitian kami, semua hipertensi krisis diawali dengan pemberian nipedipin sublingual. Nipedipin sublingual dianjurkan karena kerjanya cepat, efikasi telah terbukti serta aman, dan hanya menimbulkan sedikit efek samping, meskipun pemakaian nipedipin pada dewasa dengan fase akut masih kontroversi karena menimbulkan hipotensi yang berat dan efek neurologis. ${ }^{22}$ Kejadian tersebut jarang terjadi pada anak-anak, walaupun hipertensi krisis yang disertai ensefalopati hipertensif biasanya memerlukan pengobatan dengan anti hipertensi intravena. ${ }^{19,22}$

Pemberian tiga atau lebih anti hipertensi jarang pada anak. Pemberian seperti ini terutama diperlukan 
pada anak dengan kelainan ginjal maupun ekstra renal. Pada penelitian kami, terdapat gabungan 3 atau lebih obat anti hipertensi yang lebih sering dipakai untuk mengatasi hipertensi krisis dibandingkan pada hipertensi derajat 1 dan 2 (tabel 5). Keadaan ini juga dilaporkan oleh Yang dan Wu pada anak di Cina. ${ }^{18}$

Lama pemberian gabungan 3 obat atau lebih pada hipertensi krisis berbeda antara proses akut seperti GNA dan proses kronik seperti GGK. Pasien GGK stadium 2-4 yang disertai hipertensi dapat diawali dengan monoterapi tetapi hampir 50\% harus menggunakan lebih dari 1 obat. ${ }^{8}$ Pada GNA, kombinasi obat dapat dihentikan satu persatu apabila proses akut telah selesai.

Penelitian kami mempunyai keterbatasan karena tidak dapat membandingkan dengan kejadian tahun sebelumnya. Setelah tsunami 2004, RSUDZA belum dapat berjalan seperti biasa karena membutuhkan proses pemindahan ke rumah sakit baru, sehingga banyak data rekam medik tahun 2005 dan 2006 yang hilang. Keterbatasan lain adalah dalam mengumpulkan data dari rekam medik, ketidaksesuaian antara jumlah pasien hipertensi di buku registrasi Divisi Nefrologi dengan status yang ada di rekam medik. Walaupun demikian, hasil penelitian kami merupakan suatu awal untuk perbaikan rekam medik ke depan sehingga penelitian penelitian seperti ini akan dilakukan lebih baik lagi.

\section{Kesimpulan}

Hipertensi pada anak di RSUD Zainoel Abidin paling sering terdapat anak berumur 10-11 tahun, berupa hipertensi derajat dua, tersering disebabkan GNA. Diagnosis penyebab hipertensi pada anak berdasarkan pendekatan umur, perlu diperhatikan supaya terhindar dari kerusakan target organ, dan penurunan fungsi ginjal. Terdapat hubungan bermakna antara jumlah obat yang diberikan dengan derajat hipertensi.

\section{Daftar pustaka}

1. Task Force of Blood Pressure Control in Children. Report of the second task force of blood pressure controlin children-1987. Pediatrics 1987;79:1-25.

2. Manunta P, Bianchi G. Low-salt diet and diuretic effect on blood pressure and organ damage. J Am Soc Nephrol 2004; 15:43-6.
3. Krikken JA, Lely AT, Bakker SJL, Navis G. The effect of a shift in sodium intake on renal hemodynamics is determined by body mass index in healthy youmg men. Kidney Int 2007;71:260-5.

4. Croix B, Feig DI. Chilhood hypertension is not a silent disease. Pediatr Nephrol 2006;21:527-32.

5. Siverstein DM, Champoux E, Aviles DH, Vehaskari VM. Treatment of primary and secondary hypertension in children. Pediatr Nephrol 2006;21:820-7.

6. Alatas H. Masalah dan penanggulangan hipertensi pada anak. Sari Pediatri 1994;2:88-94.

7. Flynn JT, Mitshefe M, Pierce C, Cole SR, Parekh RS, Futh SL, Warady BA. Blood pressure in children with chronic kidney disease. A report from the chronic kidney disease in chidren study. Hypertension 2008;52:631-7.

8. Lurbe E, Cifkova R, Crulekshank JK, Dilon MS, Ferreira I, Invtt C, dkk. Management of high blood pressure in children and adolescent: recommendations of the European Society of Hypertension.J Hypertension 2009;27:17-9.

9. Mongeau IG. Pathogenesis of the essential hypertensi. Pediatr Neprol 1991;404-11.

10. The National High Blood Pressure Education Program Working Group on High Blood Pressure in Children and Adolescents. The fourth report on the diagnosis, evaluation, and treatment of high blood pressure in children and adolescents. Pediatrics 2004;114:555-76.

11. Sekarwanan N, Rachmadi D, Hilmanto D. Unit Kerja Koordinasi Nefrologi IDAI. Konsensus hipertensi pada anak. Jakarta, Badan Penerbit IDAI;2011.h.7-13.

12. Pungky AK, Damanik MP. Hipertensi pada anak di RS Dr.Sardjito Yogyakarta. Berita Kedok Masy 2006;22: 124-7.

13. Pardede SO, Trihono PP, Tambunan T. Gambaran klinis glomerulonefritis akut pada anak di departemen ilmu kesehatan anak Rumah Sakit Cipto Mangunkusumo, Jakarta. Sari Pediatri 2005;6:144-48.

14. Albar H, Rauf S, Anas J. Unit Kerja Koordinasi Nefrologi IDAI. Konsensus glomerulonefritis akut pasca streptokokus. Jakarta, Badan Penerbit IDAI; 2012.h.117.

15. Goonasekera C, Dillon MJ. Hypertension in children. Saudi J Kidney Dis Transpl 1999;10:313-24.

16. Chobanian AV, Bakris GL, Black HR,Cushman WC, Green LA, Izzo JL.jr, dkk. Joint National Committee on Prevention, Detection, Evaluation, and Treatment of High Blood Pressure; National Heart, Lung, and Blood Institute; National High Blood Pressure Education Program Coordinating Committee. Seventh report of the Joint National Committee 
on Prevention, Detection, Evaluation, and Treatment of High Blood Pressure. Hypertension 2003;42:1206-52.

17. Viera AJ, Neutze DM. Diagnosis of secondary hypertension: an age based approach. Am Fam Physician 2010;82:1471-8.

18. Yang WC, Wu HP. Clinical analysis of hypertension in children admitted to the emergency department. Pediatr Neonatol 2010;51:44-51.

19. Sinaiko AR. Treatment of hypertension in children.
Pediatr Nephrol 1994;8:603-9

20. Fivush B, Neu A, Furth S. Acute hypertensive crises in children: emergencies and urgencies. Curr Opin Pediatr 1997;9:233-6.

21. Houtman P. Management of hypertensive emergencies in children. Paed Perinatal Drug Ther 2003;5:107-10.

22. Viera AJ, Hinderliter AL. Evaluation and management of the patient with difficult-to-control or resistant hypertension. Am Fam Physician 2009;79:863-9. 